\title{
Migration, health knowledge and teenage fertility: evidence from Mexico
}

\author{
Marianna Battaglia ${ }^{1}$
}

Received: 4 March 2014 / Accepted: 13 April 2015 / Published online: 10 May 2015

(C) The Author(s) 2015. This article is published with open access at SpringerLink.com

\begin{abstract}
Migration may affect fertility and child health care of those remaining in the country of origin. Mexican data show that having at least one household member who migrated to the United States decreases the occurrence of pregnancy among teenagers by 0.339 probability points. This finding can be partially explained by the fact that teenagers in migrant households have a higher knowledge of contraceptive methods and likely practice active birth control. I use potential migration, measured as historic migration rates interacted with the proportion of adult males in the household, as an instrument to account for the endogeneity of migrant status.
\end{abstract}

Keywords Migration · Fertility $\cdot$ Health knowledge

JEL Classification $\mathrm{O} 15 \cdot \mathrm{J} 13 \cdot \mathrm{I} 12$

\section{Introduction}

Far from being a new phenomenon, Mexican migration to the United States has seen increasing flows of migrants over time. In both absolute and relative terms, their number has been larger than any other immigrant influx in the past century, corresponding nowadays to approximately seven million people and therefore $31 \%$ of the foreign

$\bowtie$ Marianna Battaglia

mbattaglia@ua.es

1 Department of Economics (FAE-Fundamentos del Análisis Económico), Universidad de Alicante, Campus de San Vicente, 03080 Alicante, Spain 
born population (U.S. Census Bureau 2006). ${ }^{1}$ According to the 2000 Mexican Census, from 1995 to $2000,4.1 \%$ of all Mexican households saw at least one family member migrating to live in the United States, while an additional $1.8 \%$ of households had family members migrating back and forth between the two countries or returning to Mexico (INEGI 2000). Overall, almost $10 \%$ of the population born in Mexico now resides in the United States (UNDP 2007). ${ }^{2}$ This paper aims at investigating the impact of this international migration on occurrence of pregnancy and child health care of women, especially teenagers, remaining in Mexico. My results show that having at least one household member who migrated to the United States decreases the occurrence of pregnancy among teenagers by 0.339 probability points. The impact observed is very large, representing a decline to 0.09 from the sample mean. This finding can be partially explained by the fact that teenagers in migrant households have a higher knowledge of contraceptive methods and likely practice active birth control. Being in a migrant household increases the knowledge of at least one contraceptive method among teenagers by 0.307 probability points on average. Less significant results are obtained for child care outcomes: being in a migrant household only raises the likelihood of the child to be delivered by a doctor in the sample of all women, especially in rural areas. This probability is estimated to increase by 0.569 probability points on average.

I focus on teenage women because delaying onset of fertility is still a policy priority in the country. Although fertility rates have decreased considerably in the last decades - the number of children per women of childbearing age decreased from 6.8 in 1970 to 2.2 in $2006^{3}$ - adolescent fertility rates have declined much more slowly. In 2005, the pregnancy rate for women between 12 and 19 years old was still 79 out of 1000 , in public institutions $21 \%$ of children were born to women under the age of 20 (CONAPO 2007), and the proportion of teenage mothers was around $17 \%$ (INEGI 2005). ${ }^{4}$ Adolescent pregnancy and childbearing are associated with a range of adverse health outcomes, including high risk of pregnancy-related diseases, unsafe abortion

\footnotetext{
1 In 2006, the U.S. civilian labor force stood at 149,668 million people, of whom 22,586 were foreign born. The fraction of the U.S. workforce aged 16 years and over composed of Mexican-born workers increased rapidly after 1970 (from 0.4 in 1970 to $4.7 \%$ in 2006). Workforce migration levels analogous to those of the 1970s were already reached in 1920 and continued rising until the late 1920s, favored by the outbreak of World War I and the Congressional action that restricted immigration from Europe (Massey et al. 2002). The following decades were characterized by a steady decline in the Mexican immigration share, which lasted until the Bracero Program was introduced in 1942 to ease the labor force shortage in the agricultural sector caused by World War II.

2 Mexico-U.S. migration is largely illegal and these are official data. Hence, they likely underestimate the phenomenon.

3 Since 1974 the Mexican government has implemented a family planning program based on persuasion: it has continuously broadcasted the jingle "Small Families Live Better" on television ("La Familia Pequeña Vive Mejor" in the 1970s and "Pocos Hijos Para Darles Mucho" in the 1980s). Although some researchers estimate that government programs have only a trivial effect, others say that such programs explain as much as $40 \%$ in fertility patterns between the 1960s and 1990s (Weil 2005).

4 In 2005, the birth rate in the U.S. among teenagers aged 15-19 was 40.5 out of 1000 women. $10.2 \%$ of births were to women aged 19 years and younger (U.S. HHS 2007). The corresponding percentages for women less than 20 giving birth are around $4 \%$ in most developed countries, while they can reach as high as $50 \%$ in some African countries (CONAPO 2007).
} 
practices, and maternal mortality. ${ }^{5}$ Adolescent mothers are also less likely than women aged 19-23 to use either antenatal or delivery care and have their infants immunized (Reynolds et al. 2006). ${ }^{6}$ Moreover, especially among the poor, adolescent childbearing is linked with lower future monthly earnings for mothers, and contributes to the persistence of poverty from one generation to the next, thus affecting long-term human capital accumulation and growth. Adolescent child bearers are themselves often born to adolescent mothers: in Mexico two-thirds of adolescent mothers have mothers who gave birth in their teens (Buvinic 1998).

The major concern in this study is the endogeneity of migrant status: family planning decisions can be related to the characteristics of migrant households themselves. The direction of the potential selection of individual into migration is a priori unclear. It is difficult to disentangle the extent to which the impacts on occurrence of pregnancy and child health care reflect the unobserved characteristics of migrants, their households or their communities as opposed to the migration experience itself. I tackle the problem by using an instrumental variable method. Potential migration-measured as historic migration levels interacted with the proportion of adult males in the household-is used as instrument for current migration. Historically, migrants have mainly come from the central-western region of the country. The states of Jalisco, Michoacán, and Guanajuato, which together accounted for about $30 \%$ of all Mexico-U.S. migrants throughout the twentieth century, are still among the principal sending states. In order to obtain variations at the household level, 1924 migration levels are interacted with the proportion of adult males in the household: in the Mexican context, the likelihood that at least one household member migrates increases with the proportion of males in the household.

The principal channels through which migration is expected to affect occurrence of pregnancy and child health care are wealth, exposure to the host country's norms and knowledge transmission to the sending country, and cost of migration. First, remittances sent back from migrants likely change household income and allow families to spend resources on different categories of expenditure, such as education and child health care. Higher levels of educational attainment and health investment are expected in households experiencing migration and receiving remittances, with consequences on human capital accumulation and family planning decisions (Cox et al. 2004). Access to education by adolescent girls may delay the onset of fertility (Breierova and Duflo 2004) and increase the opportunity cost of women's time, thus leading to changes in preferences regarding the quality and quantity of children (Becker 1960) and endowing girls with a better ability to process information, which, in turn, potentially increases

\footnotetext{
5 Despite the restrictive nature of the law in Mexico, abortion is widely practiced: in the last decades each year about $24 \%$ of women of reproductive age were estimated to have undergone an abortion and about 65 out of 100,000 annual maternal deaths were due to illegally induced abortions performed in unsanitary conditions and by unqualified personnel (United Nations 2002). A revised abortion law was passed in 2007. Pregnancy and childbirth are the leading causes of death among women aged 15-19 and the risk of maternal death during childbirth is 1.2 times higher among adolescents than among women aged 20 or older (Save the Children 2004).

${ }^{6}$ Babies born to adolescents have a $34 \%$ higher risk of death in the neonatal period, mainly due to the increased risk of low-birth weight, and have a $26 \%$ higher risk of death by age five (Bicego and Ahmad 1996).
} 
knowledge of contraception options (Rosenzweig and Schultz 1987; Duncan et al. 1991). ${ }^{7}$

Second, through exposure to the host country's practices, migrants acquire health knowledge and become more familiar with the use of contraceptive methods. In turn, they provide examples of behaviors that may be considered and copied by other family members at home. As much of the literature suggests (Fargues 2006; Beine et al. 2013; Lindstrom and Munoz-Franco 2005), migrants' behavioral norms tend to converge to those of their host country. Through the process of living and working in the receiving country, migrants acquire information and become aware of alternative models of gender roles and family relationships that they may accept and adopt. This assimilation process - a change in individual preferences - is gradual. The impact of the host country's values and norms on migrants' behavior increases with the length of migration: the longer a migrant has been in the receiving country, the more her outcomes are similar to those of a native. The adjustment in fertility behavior, however, also occurs in response to the economic opportunities and constraints present in the country of destination, and can therefore take place in the short term. Both processes happen simultaneously so it is challenging to disentangle the effects of assimilationchange in preferences-from those of adaptation-adjustment in fertility behavior due to economic opportunities and constraints (Lindstrom and Saucedo 2002). What is observed is that migrants share similar economic and institutional environments with natives and acquire information and behavioral norms of the country of residence. Fertility rate of the Mexican-born population in the United States is converging towards the non-Hispanic U.S. fertility rate (IPUMS 2010). Information and behaviors that flow from receiving to sending country communities can represent an additional pathway through which migration affects health outcomes and fertility behaviors. Kovsted et al. (2002), for instance, suggested that although maternal education is important in determining child health and mortality, its effect diminishes or disappears when health knowledge is introduced as an explanatory variable. Health knowledge crowds out the effects of mother's education and is thus not necessarily associated with the income or education of parents. The information and behaviors obtained through the experience in the receiving country therefore have the potential to result in less risky sexual behaviors and-in the long run - in better health outcomes also in the sending country. ${ }^{8}$ The strong family ties of Mexican society and the recurrence of Mexican migration to the United States make the role of migration networks as a transfer of behavioral norms from the host to the migrants' home country highly plausible.

Third, the migration of a household member decreases the cost of migration for other family members and women, especially teenagers, can decide to delay pregnancy in anticipation of future migration. Having at least one household member

\footnotetext{
7 Some elements of sex education have recently been introduced in schools of many countries due to the spread of the HIV epidemic in Africa. In Mexico, the first AIDS/HIV prevention program was introduced in schools in 2008 by the Ministerial Declaration "Prevenir con Educación".

8 I cannot control for the role of media in the transmission of behavioral norms. My data do not provide complete information on television or radio ownership. However, data available show little variation in these outcomes: $96.28 \%$ of households owns a television and $89.01 \%$ owns a radio. More precisely, $86.84 \%$ of households owns both a radio and television, $11.60 \%$ owns either a radio or television, and only $1.55 \%$ does not own either.
} 
who migrated to the United States increases the likelihood that another member who remained in the home country will try to migrate. Thus, women who do not want to get pregnant in Mexico, as this would increase their cost of migration, will acquire more knowledge of contraceptive methods and likely practice active birth control.

My data do not allow to provide a complete decomposition of the channels through which migration matters for the occurrence of pregnancy and child health care. I show some evidence of the increased knowledge of contraceptive methods among teenagers in households that experienced migration to U.S. and I argue that these girls may be better endowed to process information (thanks to higher access to education-wealth effect), decide to delay pregnancy and actively acquire more information (due to the reduced cost of migration) and are more exposed to behavioral norms of their household members' host country (knowledge transmission to the sending country). Knowledge of contraceptive methods is therefore used as a measure of more general health knowledge.

So far the literature has not largely investigated the interaction between migration and health outcomes or, even more specifically, sexual behavior. When it has, it mainly focuses on the potential effects in the country of destination, such as access to welfare benefits (Bertrand et al. 2000), health services (Menjivar 2002; Deri 2005; Devillanova 2008), and fertility (Chou 2011), but little is said about the impact of migration on these outcomes in the sending region. There are some recent contributions in this direction. Beine et al. (2013) examined the relationship between international migration and source country fertility and provided evidence of a strong transfer of fertility norms from migrants to their country of origin. Analogously, in their study on rural Guatemala, Lindstrom and Munoz-Franco (2005) found that contraceptive use increases and fertility falls with variables such as having family members in urban or international destinations and living in a community where urban migration is common. De (2013) showed that women in Mexico belonging to migrant families have a higher propensity to use modern contraceptives. Kanaiaupuni and Donato (1999), Frank and Hummer (2002), Hildebrandt and McKenzie (2005) used the same Mexican data to investigate the effects of migration on infant mortality and birth weight, finding positive effects for children living in households with at least one migrant. In Pakistan, Mansuri (2006) found that migration has a positive impact on early child growth outcomes, especially for young girls. My paper is related to this strand of the literature and attempts to provide a first, in-depth investigation of the impact of migration on occurrence of pregnancy in the country of origin, especially for adolescent women for whom delaying onset of fertility is still a policy priority in many countries.

The paper is structured as follows. Section 2 provides information on the data used in the study. The empirical strategy is presented in Sect. 3. Section 4 illustrates and interprets the results. Conclusions are drawn in the last section. 


\section{Data}

This study uses data from the Mexican National Survey of Demographic Dynamics (ENADID_Encuesta Nacional de Dinámica Demográfica) of 1997 and 2006. ${ }^{9}$ The households for which information is collected are not the same across years. Therefore, I use a pooled cross-sectional dataset. Detailed individual and household characteristics, including demographics, education and dwelling infrastructures are available in the pooled sample for 468,503 individuals in 107,654 households across all 32 Mexican states. The survey also offers information on permanent and temporary migration to the United States. For migrants, data are collected on age, sex, relationship with the head of the household, year and duration of migration, state of destination, reasons to migrate and remittances. ${ }^{10}$ Moreover, all women aged 15-54 in each household are asked detailed questions about their fertility history, knowledge and use of contraceptive methods, and child health care. For the purpose of the analysis, attention is placed on women for whom information on migration is available. The final dataset therefore comprises 39,133 women aged 15-54 in 28,433 households. Among these women, almost $21 \%$ are less than 20 years old.

International migration The ENADID survey asks each household member whether she has ever been to the United States in the 5 years prior to the day of the interview. ${ }^{11}$ This implies that I do not get information on the migration experience before 5 years prior to that day. ENADID does not ask the year of the first trip to U.S., only the last trip. Due to the way the question is asked, those who migrated and returned to Mexico before 5 years prior to the survey are not migrants in my sample. I am not particularly concerned that this definition may bias my results because Mexican migration to the United States tends to be recurrent. ${ }^{12}$ If one migrates once, it is likely that she will migrate again. If one migrates before the five-year span, she will likely migrate also in this interval. Therefore, she is part of the migrant sample. In my pooled sample, almost $54 \%$ of the individuals who migrated moved back and forth.

I am interested in the impact of previous migration experience on subsequent occurrence of pregnancy and child health care. My outcomes of interest need not be affected by the same shocks leading to the migration decision. As suggested by Hildebrandt and McKenzie (2005), I divide the 5-year period into two periods: the first 2 years and the second 3 years. The choice of using January 1994 and 2003 as thresholds depends on the way the question on the probability of getting pregnant has been posed in the survey. The information on children and on the occurrence of pregnancy was

\footnotetext{
9 The ENADID is a nationally representative demographic survey conducted by the Mexican national statistical agency (Instituto Nacional de Estadística y Geografía, INEGI) in partnership with the national public health and demographical agencies, Instituto Nacional de Salud Pública (INSP) and Consejo Nacional de Población (CONAPO).

10 Every household member of at least 12 years of age living in the household answers about her migration experience. For household members who are still abroad, information is provided by the head of the household. Some data are available only for the 2006 survey.

11 The surveys were conducted in the last quarter of 1997 and in the first quarter of 2006.

12 Mexican migrants spend 3 years/4 years in the United States before returning home after a single migration spell (Munshi 2003).
} 
collected from 1994 in the 1997 dataset and from 2003 in the 2006 dataset. Moreover, reducing the period of analysis to less than 3 years would create a too short interval of time to expect any impact of the previous migration experience. A household is defined as a migrant household if at least one adult member made her last trip to the United States between January 1st 1992 and January 1st 1994 or between January 1st 2001 and January 1st 2003, depending on the dataset. ${ }^{13}$ The occurrence of pregnancy and child health care outcomes are therefore recorded since January 1st 1994 or January 1st 2003. Migrant households account for $10 \%$ of the pooled sample. Migrants mainly move in search of a job (about $82 \%$ ) and to California and Texas (36 and $15 \%$, respectively). They are mainly young males aged on average 27 who cross the border illegally: almost $84 \%$ of them are undocumented. ${ }^{14}$ The typical migrant is either the (eldest) son of the household head $(48 \%)$ or the head of the household $(30 \%)$. Only $20 \%$ of migrant households have at least one woman migrating.

Individual and household characteristics Table 1 presents summary statistics for individual and household characteristics of the pooled sample, for both teenagers and all women.

Overall, teenagers in households with at least one member who migrated to the United States have less educated parents and live in larger families mainly in rural areas compared to teenagers in non-migrant households. No statistically significant differences between the two groups are recorded for level of education: on average, teenagers in both migrant and non-migrant households attend some years of junior high school. ${ }^{15}$ The same conclusions can be drawn for the sample of all women. These descriptive statistics are in line with much of the literature that suggests that Mexican migrants usually come from the lower middle ranges of the socioeconomic scale (Massey et al. 1994; Borjas and Katz 2007). ${ }^{16}$

Occurrence of pregnancy ENADID asks women aged 15- 54 whether they ever got pregnant, whether they gave birth or have had an abortion or miscarriage, and the number of children. The year of birth (or death, in case of death after birth) and the year of abortion are recorded. Hence, when I refer to the occurrence of pregnancy, I am exactly capturing the event of getting pregnant and not necessarily whether the woman gave birth: cases of miscarriage and especially abortion are included. Each Mexican

\footnotetext{
13 In ENADID, individuals are considered able to migrate in search of a job if they are older than 12 years old. Thus, in my study I define a person older than 12 years old as an adult.

14 The percentage found by the Mexican Migration Project (MMP) is smaller. According to the MMP, $67 \%$ of Mexican migrants who cross the border are undocumented (Munshi 2003). Since 1982, the MMP has carried out surveys in Mexican communities, most of which are located in the western part of the country, where migration to the United States is more prevalent.

15 In the Mexican education system, children aged 3-5 attend preschool (not compulsory), from 6 to 11 years old they attend primary school/primaria, from 12 to 14 junior high school/secundaria, from 15 to 17 high school/bachillerato-profesional tecnico and from 18 years old onwards university/licenciatura. Level 3 in the dataset corresponds to junior high school, which is equivalent to 9 years of completed schooling.

16 Women in migrant households have a higher monthly income than women in non-migrant households likely because these values include remittances. Nonetheless, data on remittances are inaccurate and information on income are not reliable: a high percentage of households report a monthly household income equal to zero Mexican pesos. I do not use this variable for estimation.
} 
Table 1 Summary statistics—individual characteristics

\begin{tabular}{|c|c|c|c|c|c|}
\hline & $\begin{array}{l}\text { (1) } \\
\text { Full sample }\end{array}$ & $\begin{array}{l}\text { Non-migrant } \\
\text { households }\end{array}$ & $\begin{array}{l}\text { (3) } \\
\text { Migrant } \\
\text { households }\end{array}$ & $\begin{array}{l}(4) \\
\text { Difference (2-3) }\end{array}$ & $\begin{array}{l}(5) \\
p \text { value }\end{array}$ \\
\hline \multicolumn{6}{|l|}{ Teens } \\
\hline Age & $\begin{array}{l}17.74 \\
(1.71)\end{array}$ & $\begin{array}{l}17.76 \\
(1.71)\end{array}$ & $\begin{array}{l}17.52 \\
(1.72)\end{array}$ & 0.24 & {$[0.000]$} \\
\hline Education level ${ }^{\mathrm{a}}$ & $\begin{array}{l}2.86 \\
(1.00)\end{array}$ & $\begin{array}{l}2.85 \\
(1.01)\end{array}$ & $\begin{array}{l}2.87 \\
(0.98)\end{array}$ & -0.02 & [0.491] \\
\hline $\begin{array}{l}\text { Father's education } \\
\text { level }\end{array}$ & $\begin{array}{l}2.6 \\
(1.45)\end{array}$ & $\begin{array}{l}2.65 \\
(1.48)\end{array}$ & $\begin{array}{l}2.33 \\
(1.18)\end{array}$ & 0.32 & {$[0.000]$} \\
\hline $\begin{array}{l}\text { Mother's education } \\
\text { level }\end{array}$ & $\begin{array}{l}2.4 \\
(1.28)\end{array}$ & $\begin{array}{l}2.46 \\
(1.29)\end{array}$ & $\begin{array}{l}2.25 \\
(1.10)\end{array}$ & 0.21 & {$[0.000]$} \\
\hline Couple (=1) & 0.38 & 0.39 & 0.27 & 0.12 & {$[0.000]$} \\
\hline Household size & $\begin{array}{l}6.7 \\
(3.09)\end{array}$ & $\begin{array}{l}6.7 \\
(3.10)\end{array}$ & $\begin{array}{l}7.1 \\
(3.00)\end{array}$ & -0.4 & {$[0.000]$} \\
\hline $\begin{array}{l}\text { Monthly household } \\
\text { income (Mexican } \\
\text { pesos) }^{b}\end{array}$ & $\begin{array}{l}3692 \\
(7670)\end{array}$ & $\begin{array}{l}3621 \\
(7932)\end{array}$ & $\begin{array}{l}4217 \\
(4968)\end{array}$ & -588 & {$[0.002]$} \\
\hline Rural (=1) & 0.65 & 0.64 & 0.74 & -0.10 & {$[0.000]$} \\
\hline $\begin{array}{l}\text { No. observations } \\
\quad(\max )\end{array}$ & 8158 & 7281 & 877 & & \\
\hline \multicolumn{6}{|l|}{ All women } \\
\hline Age & $\begin{array}{l}28.50 \\
(9.13)\end{array}$ & $\begin{array}{l}28.30 \\
(9.04)\end{array}$ & $\begin{array}{l}29.40 \\
(9.78)\end{array}$ & -1.10 & {$[0.000]$} \\
\hline Education level $^{\mathrm{a}}$ & $\begin{array}{l}2.96 \\
(1.46)\end{array}$ & $\begin{array}{l}2.98 \\
(1.47)\end{array}$ & $\begin{array}{l}2.86 \\
(1.36)\end{array}$ & 0.12 & {$[0.000]$} \\
\hline $\begin{array}{l}\text { Father's education } \\
\text { level }\end{array}$ & $\begin{array}{l}2.98 \\
(1.70)\end{array}$ & $\begin{array}{l}3.03 \\
(1.72)\end{array}$ & $\begin{array}{l}2.64 \\
(1.44)\end{array}$ & 0.39 & {$[0.000]$} \\
\hline $\begin{array}{l}\text { Mother's education } \\
\text { level }\end{array}$ & $\begin{array}{l}2.73 \\
(1.48)\end{array}$ & $\begin{array}{l}2.76 \\
(1.49)\end{array}$ & $\begin{array}{l}2.50 \\
(1.33)\end{array}$ & 0.26 & {$[0.000]$} \\
\hline Couple $(=1)$ & 0.73 & 0.73 & 0.69 & 0.04 & {$[0.001]$} \\
\hline Household size & $\begin{array}{l}5.99 \\
(2.73)\end{array}$ & $\begin{array}{l}5.94 \\
(2.71)\end{array}$ & $\begin{array}{l}6.37 \\
(2.83)\end{array}$ & -0.43 & {$[0.000]$} \\
\hline $\begin{array}{l}\text { Monthly household } \\
\text { income (Mexican } \\
\text { Pesos) }\end{array}$ & $\begin{array}{l}3720 \\
(7188)\end{array}$ & $\begin{array}{l}3661 \\
(7337)\end{array}$ & $\begin{array}{l}4209 \\
(5792)\end{array}$ & -548 & {$[0.000]$} \\
\hline Rural (=1) & 0.60 & 0.59 & 0.69 & -0.10 & {$[0.000]$} \\
\hline $\begin{array}{l}\text { No. observations } \\
\quad(\max )\end{array}$ & 39,133 & 34,899 & 4234 & & \\
\hline
\end{tabular}

Standard deviations in parentheses. Column 5 reports $p$ value for Student's $t$ test and test of proportions for dummies

${ }^{a}$ Level 3 corresponds to junior high school, equivalent to nine years of schooling completed. In the Mexican education system, a child aged 3-5 attends preschool (not compulsory), from 6 to 11 years old she attends primary school, from 12 to 14 junior high school, from 15 to 17 high school and from 18 years old onwards university

b 1 Mexican Peso equal to 0.12697 US dollars in 1997 and to 0.0919 in 2006 . The monthly household income ranges between 470 and 340 US dollars, approximately 
state has a different law on abortion and this could affect the number of children actually born. ${ }^{17}$ The sample includes only women and teenagers whose partner did not migrate since January 1st 1994 or 2003. As reported in Table 2, almost $41 \%$ of teenagers and $74 \%$ of all women in the sample got pregnant in the last 3 years prior to the survey. ${ }^{18}$ The difference in means between migrant and non-migrant households for both samples of teenagers and all women is statistically significant: women in migrant households - especially if less than 20 years old - are less likely to get pregnant than women in non-migrant households.

Child health care Child health care is measured by likelihood of the child to be delivered by a doctor, number of visits to the doctor during the child's first year of life, likelihood of the child to receive at least some vaccinations, ${ }^{19}$ and number of doses across all vaccinations. In Mexico, obstetric and pediatric health care provided by the public sector has high levels of effective coverage and is fairly accessible. ${ }^{20}$ Thus, small variations are expected in these outcomes of interest.

Women for which this information is available gave birth to a surviving child or to a child who died at or after birth since January 1st 1994 or 2003. For each outcome, the actual number of observations depends on the amount of missing values. The reduction of the sample with respect to the previous analysis does not correspond necessarily to cases of abortion or miscarriage, or death at or after birth. Abortion, miscarriage and child mortality do not differ between the two groups: migrant households do not record either higher child mortality, abortion, or miscarriage in my sample. I can compare surviving children between the two groups.

Unlike for the occurrence of pregnancy, no remarkable differences between nonmigrant and migrant households are found for number of visits to the doctor and the likelihood of receiving some vaccinations (Table 2). On average, teenagers' children visit a doctor 3.26 times in the first year and almost $97 \%$ of their children receive at least some doses of each vaccine, although teenagers' children in migrant households receive a significantly lower number of doses across all vaccinations. ${ }^{21}$ However,

\footnotetext{
17 I consider occurrence of pregnancy rather than number of children because I am also interested in understanding the mechanisms leading to such an event and the possible role of the knowledge of contraceptive methods. The probability of getting pregnant, independently of the outcome of pregnancy, is the most coherent outcome in this context. Moreover, teenagers most often have less than 2 children at the time of the survey.

18 These percentages are quite high due to the data construction. In order to obtain a dataset with information on both migration and fertility history, I needed to restrict the initial dataset only to women for whom both items of information are available. As a result, while in the initial 1997 dataset $67 \%$ of all women had gotten pregnant since 1994, this percentage increases to almost $80 \%$ in the final 1997 dataset. No changes occur for the 2006 dataset. The average of all women who got pregnant in the last 3 years prior to the survey in the pooled sample is $74 \%$.

19 The vaccines are tuberculosis (BCG), polio, measles, and DPT.

20 In the Mexican public system there are two types of institutions: social security institutions for workers of the formal (public and private) sector and institutions targeting the population without social security (i.e., workers of the informal sector, self-employed, unemployed, and inactive people).

21 I also consider the number of doses of each vaccine and whether the child has received complete doses of each vaccine. There are not statistically significant differences between non-migrant and migrant households. In the analysis, the results are consistent with those reported here.
} 
Table 2 Summary statistics-outcomes of interest

\begin{tabular}{|c|c|c|c|c|c|}
\hline & $\begin{array}{l}\text { (1) } \\
\text { Full sample }\end{array}$ & $\begin{array}{l}(2) \\
\text { Non-migrant } \\
\text { households }\end{array}$ & $\begin{array}{l}(3) \\
\text { Migrant } \\
\text { households }\end{array}$ & $\begin{array}{l}(4) \\
\text { Difference } \\
(2-3)\end{array}$ & $\begin{array}{l}(5) \\
p \text { value }\end{array}$ \\
\hline \multicolumn{6}{|l|}{ Teens } \\
\hline Occurrence of pregnancy & 0.41 & 0.43 & 0.29 & 0.14 & {$[0.000]$} \\
\hline \multicolumn{6}{|l|}{ Child care } \\
\hline Delivered by a doctor $^{\mathrm{a}}$ & 0.81 & 0.80 & 0.86 & -0.06 & {$[0.021]$} \\
\hline No. visits in 1 st year of life ${ }^{b}$ & $\begin{array}{l}3.26 \\
(2.83)\end{array}$ & $\begin{array}{l}3.26 \\
(2.84)\end{array}$ & $\begin{array}{l}3.30 \\
(2.69)\end{array}$ & -0.04 & [0.786] \\
\hline $\begin{array}{l}\text { Received some } \\
\text { vaccinations }^{b}\end{array}$ & 0.97 & 0.97 & 0.97 & 0.00 & [0.817] \\
\hline $\begin{array}{l}\text { No. doses across } \\
\text { vaccinations }\end{array}$ & $\begin{array}{l}6.12 \\
(2.21)\end{array}$ & $\begin{array}{l}6.14 \\
(2.19)\end{array}$ & $\begin{array}{l}5.75 \\
(2.37)\end{array}$ & 0.39 & {$[0.005]$} \\
\hline $\begin{array}{l}\text { Knowledge of at least one } \\
\text { contraceptive method }\end{array}$ & 0.82 & 0.82 & 0.85 & -0.03 & {$[0.055]$} \\
\hline No. observations (max) & 8158 & 7281 & 877 & & \\
\hline \multicolumn{6}{|l|}{ All women } \\
\hline Occurrence of pregnancy & 0.74 & 0.75 & 0.68 & 0.07 & {$[0.000]$} \\
\hline \multicolumn{6}{|l|}{ Child care } \\
\hline Delivered by a doctor ${ }^{\mathrm{a}}$ & 0.84 & 0.84 & 0.89 & -0.05 & {$[0.000]$} \\
\hline No. visits in 1 st year of life ${ }^{b}$ & $\begin{array}{l}3.55 \\
(3.02)\end{array}$ & $\begin{array}{l}3.56 \\
(3.03)\end{array}$ & $\begin{array}{l}3.49 \\
(2.98)\end{array}$ & 0.07 & [0.264] \\
\hline $\begin{array}{l}\text { Received some } \\
\text { vaccinations }^{b}\end{array}$ & 0.97 & 0.98 & 0.97 & 0.01 & {$[0.004]$} \\
\hline $\begin{array}{l}\text { No. doses across } \\
\text { vaccinations }^{b}\end{array}$ & $\begin{array}{l}6.64 \\
(1.97)\end{array}$ & $\begin{array}{l}6.65 \\
(1.96)\end{array}$ & $\begin{array}{l}6.54 \\
(2.07)\end{array}$ & 0.11 & [0.003] \\
\hline $\begin{array}{c}\text { Knowledge of at least one } \\
\text { contraceptive method }\end{array}$ & 0.90 & 0.90 & 0.92 & -0.02 & {$[0.000]$} \\
\hline
\end{tabular}

No. observations (max)

39,133

34,899

4234

Standard deviations in parentheses. Column 5 reports Student's $t$ test and test of proportions for dummies a Cases of abortion are excluded: they do not differ between the two groups

${ }^{\mathrm{b}}$ Child mortality is taken into account: it does not differ between the two groups

teenagers and women in migrant households are more likely to be assisted by a doctor when delivering than their counterparts in non-migrant households. The difference in means is statistically significant. Overall, more than $80 \%$ of women have their children delivered by a doctor, suggesting that still around $20 \%$ of deliveries may have been conducted in less safe conditions. 
Knowledge of contraceptive methods ENADID asks women aged 15-54 detailed information on the knowledge of eleven different methods of contraception and their use. ${ }^{22}$ A priori, information on the use of contraception is more relevant to explain the different occurrence of pregnancy between migrant and non-migrant households. Among sexually active teenagers, almost $70 \%$ reports having used or using contraceptive methods. ${ }^{23}$ Nonetheless, self-reported use of contraceptive methods is often unreliable: people tend to state that they use a different method than the one they actually use (Becker and Costenbader 2001). Therefore, I prefer to investigate the impact of migration on knowledge of at least one contraceptive method-it is necessary to have knowledge about at least one contraceptive method to prevent pregnancy-and infer from that the possible impact on its use: knowledge of contraceptive methods and their use are indeed positively correlated. Estimates of the impact of migration on the self-reported use of contraceptive methods are, however, provided in Table 7 in the Appendix. An initial comparison of migrant and non-migrant households reveals that migrant households know more about contraception and this difference is statistically significant. Overall, $18 \%$ of teenagers reports having no knowledge about any method to prevent pregnancy (Table 2). ${ }^{24}$

\section{Empirical strategy}

\subsection{Econometric specification}

Summary statistics show the characteristics of migrant households that are generally associated with high fertility rates and low education levels. Women, and in particular teenagers, in migrant households have less educated parents and live in larger families mainly in rural areas. Nonetheless, an initial comparison of migrant and non-migrant households reveals some differences in the outcomes of interest which suggest a lower occurrence of pregnancy and slightly higher child care for women in migrant households. These phenomena may be the result of the migration experience itself (and not of the selection mechanism into migration). In order to assess the impact of inter-

\footnotetext{
22 The questions in the survey are as follows: 1. Could you please tell me which contraceptive method/s you have heard about? Quisiera usted decirme de qué métodos o medios ha oído hablar? 2. [for every method not mentioned] Have you heard about [the name of the method]? Ha oído hablar de [método]? 3. Have you ever used [the method] to prevent pregnancy? Alguna vez usted o su pareja han usado [método] para evitar el embarazo? Only the first question is considered here to capture the knowledge of contraceptive methods because the methods directly mentioned are most likely those which are actually known and used by the woman interviewed. The eleven contraceptive practices are: birth control pills, condoms, diaphragms or sponges, intrauterine devices (IUD), injections, Norplant implants, tubal occlusion, vasectomy, natural family planning, withdrawal and the morning-after pill.

23 Teenagers report using mainly birth control pills, IUDs, and condoms. A high percentage-especially in the 1997 sample-also resort to withdrawal. Among the contraceptive methods, costless methods such as withdrawal and natural family planning are included in the survey. The economic status of the individual does not affect per se the choice to use or not methods of contraception.

24 The most known contraceptive methods are birth control pills and condoms, which are reported to be known, on average, by 72 and $56 \%$ of teenagers, respectively.
} 
national migration on the outcomes of interest, I estimate the following regression function:

$$
\begin{aligned}
F_{i j}= & \beta_{0}+\beta_{1} \text { migrants }_{j}+\beta_{2} X_{i j}+\beta_{3} \sum_{s=1}^{32} \sum_{t=1}^{2} \text { state }_{j s} \text { year }_{j t} S_{s t} \\
& +\sum_{s=1}^{32} \delta_{s} \text { state }_{j s}+\sum_{t=1}^{2} \phi_{t} \text { year }_{j t}+\epsilon_{i j}
\end{aligned}
$$

where $F_{i j}$ stands for the outcomes of interest-occurrence of pregnancy, child health care and knowledge of at least one contraceptive method-for a woman $i$ in household $j$. migrants $s_{j}$ is an indicator of whether the household $j$ has a member who migrated to the United States. The set of exogenous individual and household characteristics $X_{i j}$ includes age and age squared, proportion of adult males in the household, household size, whether the woman is in a relationship, whether the household is in a rural area, and woman's level of education. I prefer to use the last education level achieved instead of years of schooling completed because the education level is often obtained prior to the migration experience and less subject to its influence. Especially for teenagers, being in school could be influenced by the family migration experience, so years of schooling completed and dropping out of school during high school (from 15 to 17 years old) or university (from 18 years old) could be potentially endogenous. Not including education at all will, however, lead to misleading results: the literature suggests that access to education by adolescent girls may delay the onset of fertility (Breierova and Duflo 2004; Durand et al. 2001). I do not control for monthly income because of its potential endogeneity: it also likely contains remittances due to the migration experience. Data on remittances are indeed inaccurate and the available information does not allow distinguishing between the amounts due to labor income and transfers within the household. Two additional controls for the mother's education level and the presence at home of a grandmother-or another woman older than 50 years old-are included when the sample is restricted to teenagers. The rationale is that teenagers who live with a higher educated mother, or another adult women beyond the mother, may get better supervision and be endowed with a better ability to process information. $S_{s t}$ is a vector of observable state-level characteristics that capture the socioeconomic development of the Mexican state of residence. It includes two measures of health care provision taken from CONAPO (1998, 2002), namely number of hospitals per 10,000 inhabitants (by state) and number of doctors per 1000 inhabitants (by state) in the two years of the survey. state ss $_{\text {is a dummy for the } 32}$ states of residence and year ${ }_{j t}$ is a dummy for the year of the survey (1 stands for 1997 and 2 for 2006). Robust standard errors are clustered at the state-by-survey year level. 25

\footnotetext{
25 To test how sensitive my results are, I also cluster the errors around households for the entire sample. This cannot be done for the sample of teenagers because there is rarely more than one teenager between 15 and 19 years old in the same household. Qualitatively, the main results remain the same.
} 
I consider separately the sample of all women and teenagers. In addition, I include the interaction between being in a migrant household and living in rural areas to assess whether there are differences between rural and urban areas. The regression function is estimated as follows:

$$
\begin{aligned}
F_{i j}= & \beta_{0}+\beta_{1} \text { migrants }_{j}+\beta_{2} X_{i j}+\beta_{3} \sum_{s=1}^{32} \sum_{t=1}^{2} \text { state }_{j s} \text { year }_{j t} S_{s t} \\
& +\beta_{4 \text { migrants }_{j}} \times \text { rural }_{j}+\sum_{s=1}^{32} \delta_{s} \text { state }_{j s}+\sum_{t=1}^{2} \phi_{t} \text { year }_{j t}+\epsilon_{i j}
\end{aligned}
$$

where $X_{i j}$ also includes the location of the household (rural $)_{j}$.

\subsection{The endogeneity problem}

The parameter of major interest in Eq. (1) is $\beta_{1}$. Nonetheless, its identification is complicated. Migrant households are not randomly drawn from the population: family planning decisions and health care can be related to the characteristics of migrant households themselves. More educated and wealthier people tend to be more sensitive to family planning. They can decide to migrate to improve their children's opportunities. As a result, migrant households would have lower fertility and better health outcomes than non-migrant households. Vice versa, if wealthier people decide not to migrate, then migrant households tend to be the poorest and have higher fertility and worse health than non-migrant households. There is a problem of potential selection of individual into migration whose direction is a priori unclear. More formally, in Eq. (1) the error term $\epsilon_{i j}$ is composed of two parts:

$$
\epsilon_{i j}=\eta_{i j}+u_{i j}
$$

where $\eta_{i j}$ is an unobservable individual term correlated with migration and $u_{i j}$ is an unobservable individual term that is not correlated. mi grants $s_{j}$ in (1) is likely to depend on some factors captured by $\eta_{i j}$. A simple comparison of migrant and non-migrant households would therefore incorrectly estimate the gains or losses from migration. In order to separate its effect from the impacts of the selection mechanism, I use an instrumental variable strategy. I need an instrument that is correlated with the migration decision but uncorrelated with the individual unobservable attributes.

The instrument for current migration is potential migration. Foerster (1925) provides information about state-level migration networks from Mexico to the United States for the year 1924. There is substantial evidence that migration networks, formed as a result of U.S. demand conditions and the pattern of development of the northsouth railroad system in the early 1900s, play an important role in determining current migration from Mexico (among others, Massey et al. 1994; Winters et al. 2001; 
Munshi 2003). ${ }^{26}$ Those states which were the main sending states at the beginning of the century (Fig. 1) are still among the principal sending states nowadays. ${ }^{27}$

Historic migration patterns can thus be used as an instrument for current levels of migration (Hildebrandt and McKenzie 2005). The assumption is that in a community with high historical levels of migration, a household will have a higher likelihood of having one migrant member than an otherwise identical household living in a community with low initial migration rates. Nonetheless, the use of historical migration networks at the state level may give rise to possible concerns: 1924 migration patterns may be correlated with state-level unobservables that can affect the state average outcomes. Variations at the household level would be preferable. Historical migration networks are thus interacted with the proportion of adult males (more than 12 years old) in the household, including those who have migrated and are still in the United States. ${ }^{28}$ In the Mexican context, the likelihood that members of a household will migrate increases with the number of males in the household: typical migrants are the sons of the household head or the male head himself. ENADID data suggest that households with a single adult male are less likely to have a member who migrates (9\%) than households with three or more adult males (14\%), conditional on the same household size and the same number of adults in the household. For instance, take two households with five adult members (more than 12 years old) and the same household size: household A has two men and three women, household B has three men and two women. Household A is less likely to undertake migration than household B. Variations at the household level are given by the proportion of males among adult members.

\footnotetext{
26 Three major north-south railroad lines were built in Mexico between 1884 and 1900. The first, the Central Mexican Railroad, went south from what is now Ciudad Juarez-connected to the Southern Pacific and Texas Pacific railroads in Texas-to the state of Guanajuato, where it branched east to Mexico City and west through Guadalajara to Colima. A second line, the Mexican International Railroad, ran from Durango through Chihuahua to Piedras Negras until Texas. The third, the Mexican National Railroad, travelled north from Mexico City through San Luis Potosi and Monterrey, reaching the border at Nuevo Laredo (Woodruff 2007).

27 Historically, migrants have mainly come from the central-western region of the country: Aguascalientes, Jalisco, Michoacán, Coahuila, Zacatecas and Durango. The lowest migration rates are registered in the southern states of Chiapas, Oaxaca, Yucatán and Guerrero. In the twentieth century, residents of Jalisco, Michoacán, and Guanajuato were roughly twice as likely to migrate as the average Mexican. Just $1.5 \%$ of migrants came from Chiapas, Campeche, Yucatán and Quintana Roo, which are home to $7 \%$ of the population (Durand et al. 2001). The data indicate that the high-migration states were, on average, poorer than the low-migration states during the first half of the century and had a lower level of pre-migration measures of health, education and income.

28 This method is similar in spirit to Mansuri (2006). In her study on Pakistan, she uses prevalence rates of migration together with census-level information on land ownership in the village to obtain within-village variation. By interacting the village-land group migration network with the number of adult males in a household, she obtaines an instrument which varies at the household level.
} 

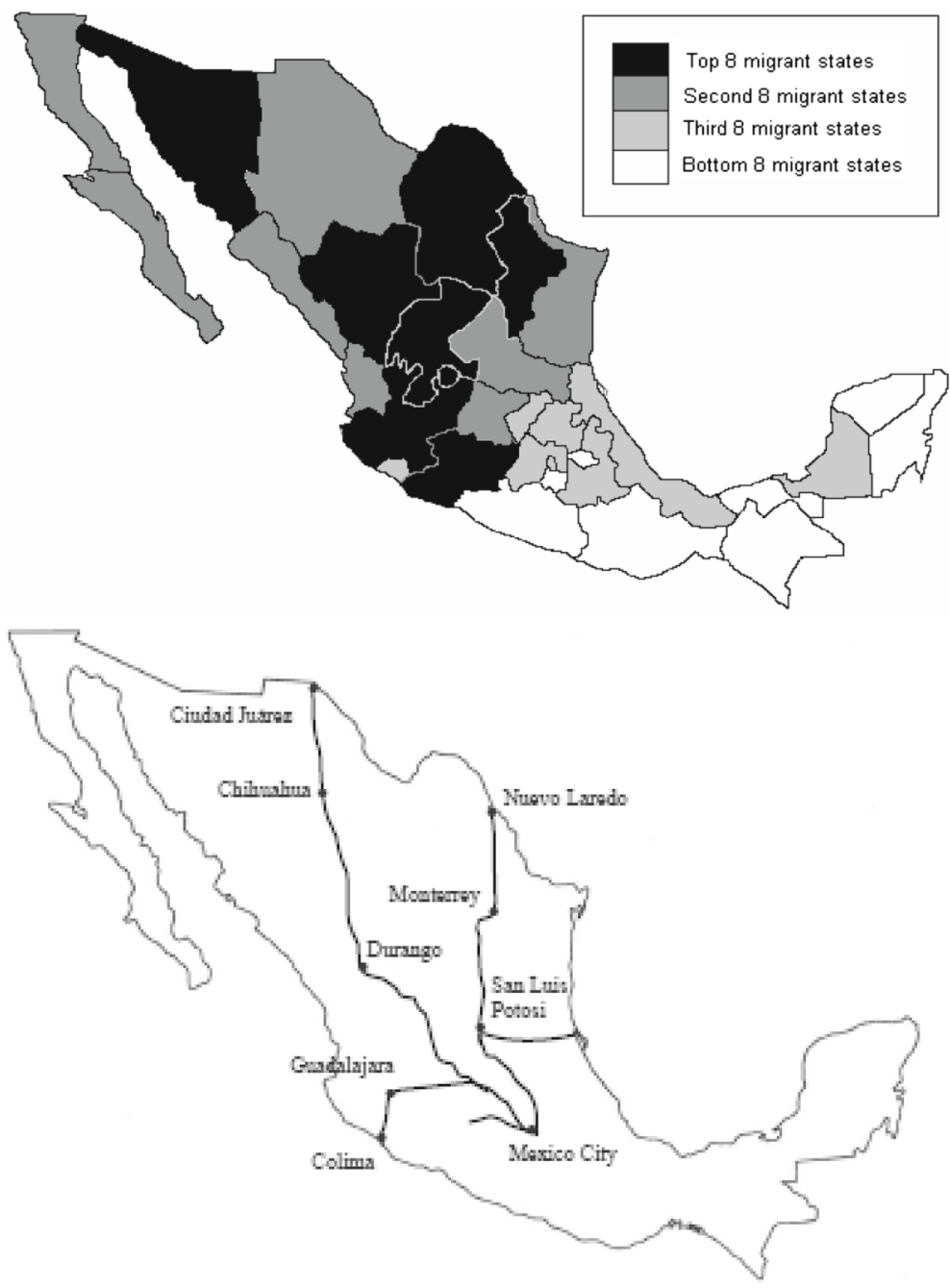

Fig. 1 Historical migration rates and Railroad system in early 1900s. Source Hildebrandt and McKenzie (2005), Woodruff (2007)

migrants $s_{j}$ in a reduced form framework is therefore modeled as follows:

$$
\begin{aligned}
\text { migrants }_{j}= & \alpha_{0}+\alpha_{1} \text { potentialmigrants }_{j}+\alpha_{2} X_{i j}+\alpha_{3} \sum_{s=1}^{32} \sum_{t=1}^{2} \text { state }_{j s} \text { year }_{j t} S_{s t} \\
& +\sum_{s=1}^{32} \sigma_{s} \text { state }_{j s}+\sum_{t=1}^{2} \gamma_{t} \text { year }_{j t}+\eta_{i j}+v_{j}
\end{aligned}
$$


where potentialmigrants $s_{j}$ is a continuous variable equal to the 1924 state migration rate interacted with the proportion of adult males in the household. As an instrument for the interaction term migrants ${ }_{j} \times$ rural $_{j}$ in (2), I use potentialmigrants interacted with the dummy for the location of the household $\left(\mathrm{rural}_{j}\right)$. The instrument affects the household's propensity to send members abroad but is unlikely to be correlated with any unobservable household or women attributes that affect the occurrence of pregnancy and child health care (and knowledge of contraceptive methods). The assumption here is that, conditional on household demographic characteristics and state fixed effects, the proportion of adult males does not affect the outcomes of interest differently by state, but it does affect the propensity that someone in the family would migrate. One could argue that children's gender composition influences women's fertility and therefore the proportion of adult males in a household can affect the occurrence of pregnancy. Angrist and Evans (1998), among others, show that parents of same-sex siblings are significantly and substantially more likely to go on to have an additional child. My data do not suggest it is the case here. As reported in Table 8 in Appendix, further child-bearing is not more likely for women with the oldest two children of the same sex. No statistically significant differences are found between women with two girls compared to women with two boys either. There might be a preference for firstborn to be male, but the preference for male children fades out when passing from two to three children and on average women have 3.25 children. ${ }^{29}$ The potential concern of endogeneity through children's gender composition is of second order in this context. Moreover, this unlikely affects teenagers who, on average, have one child: only $3 \%$ of my teenage sample has more than two kids. The coefficients of the instrument of the reduced form (3) with and without controls are reported in columns 1-4 of Table 3.

The first-stage results for the instrumental variable estimation show that F-statistics on the incidence of migration are above 10, suggesting that after controlling for the remaining exogenous regressors, the historical migration rates interacted with the proportion of adult males in the household can be a strong determinant of whether a household currently has a migrant member. ${ }^{30}$ The coefficients of the instrument are positive, as expected, and highly statistically significant.

The estimates reported in this study are obtained through OLS and standard twostage least squares estimation (2SLS). The IV estimation method for linear regressions has been preferred to a IV probit estimator also in the case of binary outcomes because it

\footnotetext{
29 The reduced number of observations with respect to the main analysis is due to missing values, especially regarding the year of birth of older siblings.

30 The strength of the rejection of the null hypothesis of independence between errors is important in determining the finite sample properties of the IV estimator, particularly the bias. The Stock and Yogo (2005) test has also been estimated. Here theory does not apply exactly because of heteroskedasticity: the test uses default standard errors in the first-stage regression, while I use robust standard errors. The null hypothesis of weak instruments can be rejected at $5 \%$ of distortion.
} 
Table 3 First-stage

$\begin{array}{llll}(1) & (2) & (3) & (4) \\ \text { OLS } & \text { OLS } & \text { OLS } & \text { OLS } \\ \text { all } & \text { teenagers } & \text { all } & \text { teenagers }\end{array}$

Dep.var: whether there is at least one migrant in the household

Potential migrants

$\begin{array}{ll}0.696 * * * & 0.684 * * \\ (0.138) & (0.287)\end{array}$

$0.788 * * *$

$0.973 * * *$

(0.138)

$(0.287)$

(0.159)

(0.352)

Age

0.001

0.043

A

(0.001)

(0.060)

Age squared

0.000

$-0.001$

Education level

(0.000)

Proportion adult males (household)

$-0.001$

$-0.002$

(0.002)

(0.006)

Proportion adult males (household)

$0.122 * * *$

$0.117 * * *$

Household size

$0.007 * * *$

0.005

(0.002)

Couple

$-0.014 * * *$

$-0.006$

(0.005)

Rural

$0.042 * * *$

$0.048 * * *$

(0.009)

(0.018)

$-0.009$

Mother's education level

Presence of a grandmother

(0.020)

\begin{tabular}{lllll}
\hline State FEs & Yes & Yes & Yes & Yes \\
Year FEs & Yes & Yes & Yes & Yes \\
State $\times$ year FEs & Yes & Yes & Yes & Yes \\
\hline No. observations & 38,448 & 8022 & 36,421 & 3095 \\
R-squared & 0.047 & 0.060 & 0.057 & 0.098 \\
F-statistic (instrument) & 25.59 & 10.43 & 24.72 & 42.26 \\
\hline
\end{tabular}

Robust standard errors clustered at the state-by-survey year level in parentheses, * Significant at $10 \%$, ** Significant at $5 \%, * * *$ Significant at $1 \%$

requires fewer distributional assumptions and consistently estimates average treatment effects in the case of binary endogenous variables (Newey 1987; Angrist 1991). ${ }^{31}$

31 IV probit requires joint normality and homoskedasticity. Moreover, it would not precisely estimate
the first-stage: it provides least-squares (LPM) estimates of the first-stage, while the binary nature of the
endogenous regressor-whether there is at least one migrant member in the household-would require
probit estimates. Nonetheless, I also obtain estimates with IV probit and they confirm the main results.
Although I only report OLS and 2 SLS for the continuous variable (number of visits to the doctor in the
first year of life of the child), I also use the treatment effect model. It adds more structure to explicitly
account for the binary nature of the endogenous regressor by changing the first-stage model to a latent- 


\section{Results}

I proceed as follows. First, I investigate the impact of international migration on occurrence of pregnancy and child health care of women remaining in the country of origin. Knowledge of measures to prevent unwanted pregnancy can partly explain changes in fertility behaviors and accounts for broader health knowledge that can affect child health care outcomes. Therefore, by using the same specification, I secondly measure the impact of international migration on knowledge of at least one contraceptive method by women remaining in the sending country. This knowledge can be the result of increased access to education thanks to changes in household income due to remittances (wealth effect), the migration experience per se-the transfer of behavioral norms from receiving to sending country communities, and the reduction of the cost to migrate (teenagers actively acquire more information). My data do not allow to properly disentangle these channels. However, I can document that remittances sent back from migrants increase households' wealth in this context. Results are reported in Sect. A.3 in Appendix.

Occurrence of pregnancy and child health care Table 4 presents the estimation results for the occurrence of pregnancy. The difference between OLS (columns 1 and 2) and 2SLS (columns 3 and 4) estimates of migrants indicates a positive selection into migration. By simply comparing migrant households and non-migrant households I would have obtained results driven by the characteristics of migrants' households themselves: migrant households' characteristics are generally associated with higher fertility rates than non-migrant households. The coefficient estimates for the individual characteristics confirm what is expected. The age of the woman matters only for the entire sample, with an expected inverted U-shape. The higher the education level of a woman, the lower her chance of getting pregnant, especially for teenagers. The higher the education level of her mother, the lower the teenager's chance of getting pregnant. Being in a larger family reduces the occurrence of pregnancy for all women, while the presence at home of a grandmother-or a woman older than 50 years old besides the mother-does not seem to affect the outcome. Being in a relationship evidently increases the occurrence of pregnancy. The location of the household in a rural area does not significantly affect the outcome of interest. The proportion of adult males in the household is statistically significant here, plausibly capturing a size effect: conditional on the same household size, the higher the number of adult males, the lower the number of adult women who can get pregnant in the same household.

Columns 3 and 4 report the 2SLS estimates for the sample of all women and teenagers separately. Despite the imprecision of point estimates, the results show that having at least one household member who migrated to the United States decreases the occurrence of pregnancy among women. This is especially true for teenagers, whose reduction in occurrence of pregnancy corresponds, on average, to 0.339 probability

Footnote 31 continued

variable model similar to the probit and may increase precision of estimation. However, its cost is greater chance of misspecification error and if the errors are heteroskedastic the treatment effect estimator becomes inconsistent. Estimates with this model confirm the main findings. The results with the IV probit and the treatment effect model are not reported but are available upon request. 
Table 4 Occurrence of pregnancy

\begin{tabular}{|c|c|c|c|c|c|c|}
\hline & $\begin{array}{l}(1) \\
\text { OLS } \\
\text { all }\end{array}$ & $\begin{array}{l}(2) \\
\text { OLS } \\
\text { teenagers }\end{array}$ & $\begin{array}{l}(3) \\
2 S L S \\
\text { all }\end{array}$ & $\begin{array}{l}\text { (4) } \\
\text { 2SLS } \\
\text { teenagers }\end{array}$ & $\begin{array}{l}(5) \\
2 S L S \\
\text { all }^{\mathrm{a}}\end{array}$ & $\begin{array}{l}(6) \\
2 \text { SLS } \\
\text { teenagers }^{\mathrm{a}}\end{array}$ \\
\hline Migrants & $\begin{array}{l}0.003 \\
(0.005)\end{array}$ & $\begin{array}{l}-0.020 \\
(0.020)\end{array}$ & $\begin{array}{l}-0.016 \\
(0.162)\end{array}$ & $\begin{array}{l}-0.339 * * \\
(0.171)\end{array}$ & $\begin{array}{l}0.035 \\
(0.225)\end{array}$ & $\begin{array}{l}-0.363 \\
(0.332)\end{array}$ \\
\hline Age & $\begin{array}{l}0.053 * * * \\
(0.002)\end{array}$ & $\begin{array}{l}0.120 \\
(0.081)\end{array}$ & $\begin{array}{l}0.053 * * * \\
(0.002)\end{array}$ & $\begin{array}{l}0.128 \\
(0.084)\end{array}$ & $\begin{array}{l}0.053 * * * \\
(0.002)\end{array}$ & $\begin{array}{l}0.126 \\
(0.083)\end{array}$ \\
\hline Age squared & $\begin{array}{l}-0.001^{* * *} \\
(0.000)\end{array}$ & $\begin{array}{l}-0.002 \\
(0.002)\end{array}$ & $\begin{array}{l}-0.001^{* * * *} \\
(0.000)\end{array}$ & $\begin{array}{l}-0.002 \\
(0.002)\end{array}$ & $\begin{array}{l}-0.001 * * * \\
(0.000)\end{array}$ & $\begin{array}{l}-0.002 \\
(0.002)\end{array}$ \\
\hline Education level & $\begin{array}{l}-0.014 * * * \\
(0.002)\end{array}$ & $\begin{array}{l}-0.039 * * * \\
(0.007)\end{array}$ & $\begin{array}{l}-0.014 * * * \\
(0.002)\end{array}$ & $\begin{array}{l}-0.040 * * * \\
(0.008)\end{array}$ & $\begin{array}{l}-0.014 * * * \\
(0.002)\end{array}$ & $\begin{array}{l}-0.040^{* * *} \\
(0.008)\end{array}$ \\
\hline $\begin{array}{l}\text { Proportion adult } \\
\text { males (household) }\end{array}$ & $\begin{array}{l}-0.141^{* * *} \\
(0.013)\end{array}$ & $\begin{array}{l}-0.072 * \\
(0.039)\end{array}$ & $\begin{array}{l}-0.141^{* * * *} \\
(0.013)\end{array}$ & $\begin{array}{l}-0.076^{*} \\
(0.039)\end{array}$ & $\begin{array}{l}-0.141 * * * \\
(0.013)\end{array}$ & $\begin{array}{l}-0.077 * * \\
(0.039)\end{array}$ \\
\hline Household size & $\begin{array}{l}-0.017 * * * \\
(0.001)\end{array}$ & $\begin{array}{l}-0.017 * * * \\
(0.003)\end{array}$ & $\begin{array}{l}-0.017 * * * \\
(0.001)\end{array}$ & $\begin{array}{l}-0.014 * * * \\
(0.004)\end{array}$ & $\begin{array}{l}-0.017 * * * \\
(0.001)\end{array}$ & $\begin{array}{l}-0.014 * * * \\
(0.004)\end{array}$ \\
\hline Couple & $\begin{array}{l}0.383 * * * \\
(0.015)\end{array}$ & $\begin{array}{l}0.568 * * * \\
(0.014)\end{array}$ & $\begin{array}{l}0.383 * * * \\
(0.015)\end{array}$ & $\begin{array}{l}0.572 * * * \\
(0.016)\end{array}$ & $\begin{array}{l}0.383 * * * \\
(0.015)\end{array}$ & $\begin{array}{l}0.572 * * * \\
(0.016)\end{array}$ \\
\hline $\begin{array}{l}\text { Mother's education } \\
\text { level }\end{array}$ & & $\begin{array}{l}-0.012 * * * \\
(0.004)\end{array}$ & & $\begin{array}{l}-0.014 * * * \\
(0.005)\end{array}$ & & $\begin{array}{l}-0.015^{* * *} \\
(0.005)\end{array}$ \\
\hline $\begin{array}{l}\text { Presence of a } \\
\text { grandmother }\end{array}$ & & $\begin{array}{l}0.024 \\
(0.015)\end{array}$ & & $\begin{array}{l}0.015 \\
(0.016)\end{array}$ & & $\begin{array}{l}0.015 \\
(0.016)\end{array}$ \\
\hline Rural & $\begin{array}{l}-0.001 \\
(0.004)\end{array}$ & $\begin{array}{l}0.008 \\
(0.014)\end{array}$ & $\begin{array}{l}-0.000 \\
(0.008)\end{array}$ & $\begin{array}{l}0.024 \\
(0.016)\end{array}$ & $\begin{array}{l}0.009 \\
(0.011)\end{array}$ & $\begin{array}{l}0.019 \\
(0.034)\end{array}$ \\
\hline Rural $\times$ migrants & & & & & $\begin{array}{l}-0.093 \\
(0.141)\end{array}$ & $\begin{array}{l}0.037 \\
(0.279)\end{array}$ \\
\hline State FEs & Yes & Yes & Yes & Yes & Yes & Yes \\
\hline Year FEs & Yes & Yes & Yes & Yes & Yes & Yes \\
\hline State $\times$ year FEs & Yes & Yes & Yes & Yes & Yes & Yes \\
\hline No. observations & 36,421 & 3095 & 36,421 & 3095 & 36,421 & 3095 \\
\hline
\end{tabular}

Robust standard errors clustered at the state-by-survey year level in parentheses: * significant at $10 \%$, $* *$ significant at $5 \%, * * *$ significant at $1 \%$

${ }^{a}$ Columns 5 and 6 report estimates for specification (2). Both migrants and migrants $\times$ rural are instrumented. The instruments are potential migrants and potential migrants $\times$ rural

points. The impact observed is very large, representing a decline to 0.09 from the sample mean. Columns 5 and 6 control for the location of the household. The coefficient for the total effect of being in a migrant household for teenagers is still statistically significant at $5 \%$ (it corresponds to -0.326), but the results show that there is not a differential impact due to the fact that the household is located in a rural or urban area. Moreover, teenagers in migrant households in urban areas have a lower likelihood of getting pregnant than their peers in non-migrant households, but results are not statistically significant. 
Table 5 Child care

\begin{tabular}{|c|c|c|c|c|c|c|}
\hline & $\begin{array}{l}(1) \\
\text { OLS } \\
\text { all }\end{array}$ & $\begin{array}{l}(2) \\
\text { OLS } \\
\text { teenagers }\end{array}$ & $\begin{array}{l}(3) \\
2 S L S \\
\text { all }\end{array}$ & $\begin{array}{l}(4) \\
\text { 2SLS } \\
\text { teenagers }\end{array}$ & $\begin{array}{l}(5) \\
2 S L S \\
\text { all }^{\mathrm{a}}\end{array}$ & $\begin{array}{l}(6) \\
\text { 2SLS } \\
\text { teenagers }^{\text {a }}\end{array}$ \\
\hline \multicolumn{7}{|c|}{ Dep.var: whether the child has been delivered by a doctor } \\
\hline Migrants & $\begin{array}{l}0.034 * * * \\
(0.010)\end{array}$ & $\begin{array}{l}0.033 \\
(0.032)\end{array}$ & $\begin{array}{l}0.569 * * \\
(0.224)\end{array}$ & $\begin{array}{l}0.022 \\
(0.355)\end{array}$ & $\begin{array}{l}-0.363 \\
(0.405)\end{array}$ & $\begin{array}{l}-1.261 \\
(1.292)\end{array}$ \\
\hline Rural & $\begin{array}{l}-0.110 * * * \\
(0.015)\end{array}$ & $\begin{array}{l}-0.120 * * * \\
(0.022)\end{array}$ & $\begin{array}{l}-0.129 * * * \\
(0.017)\end{array}$ & $\begin{array}{l}-0.119 * * * \\
(0.028)\end{array}$ & $\begin{array}{l}-0.223^{* * *} \\
(0.041)\end{array}$ & $\begin{array}{l}-0.220 * * * \\
(0.056)\end{array}$ \\
\hline Rural $\times$ migrants & & & & & $\begin{array}{l}1.151 * * * \\
(0.444)\end{array}$ & $\begin{array}{l}1.307 \\
(0.821)\end{array}$ \\
\hline No. observations & 23,869 & 1046 & 23,869 & 1046 & 23,869 & 1046 \\
\hline \multicolumn{7}{|c|}{ Dep.var: number of visits in the first year of life of the child } \\
\hline Migrants & $\begin{array}{l}0.023 \\
(0.073)\end{array}$ & $\begin{array}{l}-0.134 \\
(0.290)\end{array}$ & $\begin{array}{l}-3.021 \\
(5.814)\end{array}$ & $\begin{array}{l}-1.476 \\
(12.371)\end{array}$ & $\begin{array}{l}-1.607 \\
(7.930)\end{array}$ & $\begin{array}{l}-1.059 \\
(17.309)\end{array}$ \\
\hline Rural & $\begin{array}{l}-0.669 * * * \\
(0.089)\end{array}$ & $\begin{array}{l}-0.289 \\
(0.225)\end{array}$ & $\begin{array}{l}-0.555^{* *} \\
(0.232)\end{array}$ & $\begin{array}{l}-0.178 \\
(1.041)\end{array}$ & $\begin{array}{l}-0.256 \\
(0.425)\end{array}$ & $\begin{array}{l}-0.097 \\
(0.539)\end{array}$ \\
\hline Rural $\times$ migrants & & & & & $\begin{array}{l}-3.156 \\
(6.045)\end{array}$ & $\begin{array}{l}-0.773 \\
(9.835)\end{array}$ \\
\hline No. observations & 28,085 & 1219 & 28,085 & 1219 & 28,085 & 1219 \\
\hline \multicolumn{7}{|c|}{ Dep.var: whether the child has received some vaccinations } \\
\hline Migrants & $\begin{array}{l}-0.006^{*} \\
(0.003)\end{array}$ & $\begin{array}{l}-0.005 \\
(0.016)\end{array}$ & $\begin{array}{l}-0.038 \\
(0.135)\end{array}$ & $\begin{array}{l}-0.043 \\
(0.083)\end{array}$ & $\begin{array}{l}-0.078 \\
(0.217)\end{array}$ & $\begin{array}{l}0.583 \\
(0.516)\end{array}$ \\
\hline Rural & $\begin{array}{l}-0.004 * * \\
(0.002)\end{array}$ & $\begin{array}{l}-0.001 \\
(0.013)\end{array}$ & $\begin{array}{l}-0.003 \\
(0.005)\end{array}$ & $\begin{array}{l}0.002 \\
(0.011)\end{array}$ & $\begin{array}{l}-0.008 \\
(0.008)\end{array}$ & $\begin{array}{l}0.047 \\
(0.030)\end{array}$ \\
\hline Rural $\times$ migrants & & & & & $\begin{array}{l}0.059 \\
(0.131)\end{array}$ & $\begin{array}{l}-0.592 \\
(0.420)\end{array}$ \\
\hline No. observations & 36,394 & 1425 & 36,394 & 1425 & 36,394 & 1425 \\
\hline \multicolumn{7}{|c|}{ Dep.var: number of doses across all vaccinations } \\
\hline Migrants & $\begin{array}{l}-0.046 \\
(0.051)\end{array}$ & $\begin{array}{l}0.294 \\
(0.223)\end{array}$ & $\begin{array}{l}1.794 \\
(2.033)\end{array}$ & $\begin{array}{l}1.001 \\
(1.887)\end{array}$ & $\begin{array}{l}3.166 \\
(3.354)\end{array}$ & $\begin{array}{l}9.092 \\
(7.093)\end{array}$ \\
\hline Rural & $\begin{array}{l}0.002 \\
(0.044)\end{array}$ & $\begin{array}{l}-0.085 \\
(0.189)\end{array}$ & $\begin{array}{l}-0.058 \\
(0.088)\end{array}$ & $\begin{array}{l}-0.125 \\
(0.209)\end{array}$ & $\begin{array}{l}0.112 \\
(0.175)\end{array}$ & $\begin{array}{l}0.450 \\
(0.423)\end{array}$ \\
\hline Rural $\times$ migrants & & & & & $\begin{array}{l}-1.991 \\
(2.358)\end{array}$ & $\begin{array}{l}-7.540 \\
(5.328)\end{array}$ \\
\hline No. observations & 36,219 & 1418 & 36,219 & 1418 & 36,219 & 1418 \\
\hline
\end{tabular}

Robust standard errors clustered at the state-by-survey year level in parentheses: * significant at $10 \%$, ** significant at $5 \%, * * *$ significant at $1 \%$

All specifications include individual characteristics, state FEs, year FEs and state $\times$ year FEs

Mortality selection is taken into account in the estimations

${ }^{a}$ Columns 5 and 6 report estimates for specification (2). Both migrants and migrants $\times$ rural are instrumented. The instruments are potential migrants and potential migrants $\times$ rural 
Results for child health care outcomes are reported in Table 5. The only remarkable difference between migrant and non-migrant households can be found for the likelihood of the child to be delivered by a doctor in the sample of all women. Being in a household with at least one migrant is estimated to raise the probability that the child is delivered by a doctor by 0.569 probability points on average. Columns 5 and 6 control for the location of the household. The coefficient for the total effect of being in a migrant household for all women is still statistically significant at $1 \%$ (it corresponds to 0.787 ) and the results show that women in migrant households in rural areas are more likely to have their child delivered by a doctor than women in migrant households in urban areas. There are no statistically significant differences in child health care for teenagers in migrant and in non-migrant households.

Knowledge of at least one contraceptive method An increase in the knowledge of methods to prevent pregnancy partially explains the reduction in the occurrence of pregnancy. Knowledge is positively correlated with use of contraceptive methods and the use of contraception leads to a reduction in the occurrence of pregnancy. Moreover, knowledge of contraceptive methods can be associated with more general health knowledge and be informative of different child health care measures. Table 6 reports the estimates for the knowledge of at least one contraceptive method. The dependent variable is a dummy equal to one when the woman has knowledge of at least one method to prevent pregnancy.

Being in migrant households increases the knowledge of contraceptive methods among women, especially teenagers (columns 3 and 4). More precisely, being in a migrant household increases the knowledge of at least one contraceptive method among teenagers by 0.307 probability points on average. ${ }^{32}$ The coefficient estimates for the individual characteristics confirm what is expected. The higher the education level, the higher the knowledge of at least one contraceptive method. The education level of the mother is no longer statistically significant, while the presence of a grandmother in the household increases the likelihood that the teenager will have knowledge about a method to prevent pregnancy. The proportion of adult males in the household is not statistically significant. Women and teenagers in non-migrant households living in rural areas have lower knowledge of contraceptive methods than peers in non-migrants households living in urban areas. Columns 5 and 6 show that both women and teenagers in migrant households have a higher knowledge of contraceptive methods: the coefficient for the total effect of being in a migrant household corresponds to 0.281 , statistically significant at the $5 \%$, for all women and to 0.304 , statistically significant at $10 \%$, for teenagers. Moreover, women in migrant households in rural areas have a higher knowledge of contraceptive methods ( 0.286 probability points more) than women in migrant households in urban areas.

The results are suggestive of the existence of a health information channel due to the migration experience, which can partially drive the observed reduction in teenagers'

\footnotetext{
32 The coefficient estimate for migrants in column 3 is statistically significant when clustering at the household level.
} 
Table 6 Knowledge of at least one contraceptive method

\begin{tabular}{|c|c|c|c|c|c|c|}
\hline & $\begin{array}{l}(1) \\
\text { OLS } \\
\text { all }\end{array}$ & $\begin{array}{l}(2) \\
\text { OLS } \\
\text { teenagers }\end{array}$ & $\begin{array}{l}(3) \\
2 S L S \\
\text { all }\end{array}$ & $\begin{array}{l}(4) \\
\text { 2SLS } \\
\text { teenagers }\end{array}$ & $\begin{array}{l}(5) \\
2 S L S \\
\mathrm{all}^{\mathrm{a}}\end{array}$ & $\begin{array}{l}(6) \\
2 \text { SLS } \\
\text { teenagers }\end{array}$ \\
\hline Migrants & $\begin{array}{l}0.021 * * * \\
(0.006)\end{array}$ & $\begin{array}{l}0.056^{* * * *} \\
(0.016)\end{array}$ & $\begin{array}{l}0.153 \\
(0.115)\end{array}$ & $\begin{array}{l}0.307 * * \\
(0.156)\end{array}$ & $\begin{array}{l}0.004 \\
(0.182)\end{array}$ & $\begin{array}{l}0.314 \\
(0.212)\end{array}$ \\
\hline Age & $\begin{array}{l}0.017 * * * \\
(0.001)\end{array}$ & $\begin{array}{l}0.143 \\
(0.120)\end{array}$ & $\begin{array}{l}0.017 * * * \\
(0.001)\end{array}$ & $\begin{array}{l}0.139 \\
(0.121)\end{array}$ & $\begin{array}{l}0.017 * * * \\
(0.001)\end{array}$ & $\begin{array}{l}0.140 \\
(0.119)\end{array}$ \\
\hline Age squared & $\begin{array}{l}-0.000 * * * \\
(0.000)\end{array}$ & $\begin{array}{l}-0.004 \\
(0.003)\end{array}$ & $\begin{array}{l}-0.000 * * * \\
(0.000)\end{array}$ & $\begin{array}{l}-0.004 \\
(0.003)\end{array}$ & $\begin{array}{l}-0.000 * * * \\
(0.000)\end{array}$ & $\begin{array}{l}-0.004 \\
(0.003)\end{array}$ \\
\hline Education level & $\begin{array}{l}0.022 * * * \\
(0.002)\end{array}$ & $\begin{array}{l}0.076 * * * \\
(0.008)\end{array}$ & $\begin{array}{l}0.023 * * * \\
(0.002)\end{array}$ & $\begin{array}{l}0.077 * * * \\
(0.008)\end{array}$ & $\begin{array}{l}0.023 * * * \\
(0.002)\end{array}$ & $\begin{array}{l}0.077 * * * \\
(0.008)\end{array}$ \\
\hline $\begin{array}{l}\text { Proportion adult } \\
\text { males (household) }\end{array}$ & $\begin{array}{l}0.003 \\
(0.014)\end{array}$ & $\begin{array}{l}0.014 \\
(0.044)\end{array}$ & $\begin{array}{l}0.004 \\
(0.014)\end{array}$ & $\begin{array}{l}0.024 \\
(0.046)\end{array}$ & $\begin{array}{l}0.004 \\
(0.015)\end{array}$ & $\begin{array}{l}0.024 \\
(0.045)\end{array}$ \\
\hline Household size & $\begin{array}{l}-0.008 * * * \\
(0.001)\end{array}$ & $\begin{array}{l}-0.011 * * * \\
(0.003)\end{array}$ & $\begin{array}{l}-0.009 * * * \\
(0.002)\end{array}$ & $\begin{array}{l}-0.012 * * * \\
(0.003)\end{array}$ & $\begin{array}{l}-0.009 * * * \\
(0.002)\end{array}$ & $\begin{array}{l}-0.012 * * * \\
(0.003)\end{array}$ \\
\hline Couple & $\begin{array}{l}0.066^{* * * *} \\
(0.005)\end{array}$ & $\begin{array}{l}0.093 * * * \\
(0.014)\end{array}$ & $\begin{array}{l}0.067 * * * \\
(0.006)\end{array}$ & $\begin{array}{l}0.090 * * * \\
(0.014)\end{array}$ & $\begin{array}{l}0.069 * * * \\
(0.006)\end{array}$ & $\begin{array}{l}0.090 * * * \\
(0.014)\end{array}$ \\
\hline $\begin{array}{l}\text { Mother's education } \\
\text { level }\end{array}$ & & $\begin{array}{l}-0.006 \\
(0.006)\end{array}$ & & $\begin{array}{l}-0.004 \\
(0.005)\end{array}$ & & $\begin{array}{l}-0.004 \\
(0.005)\end{array}$ \\
\hline $\begin{array}{l}\text { Presence of a } \\
\text { grandmother }\end{array}$ & & $\begin{array}{l}0.034 \\
(0.023)\end{array}$ & & $\begin{array}{l}0.042 * * \\
(0.021)\end{array}$ & & $\begin{array}{l}0.042 * * \\
(0.022)\end{array}$ \\
\hline Rural & $\begin{array}{l}-0.054 * * * \\
(0.007)\end{array}$ & $\begin{array}{l}-0.093 * * * \\
(0.015)\end{array}$ & $\begin{array}{l}-0.060 * * * \\
(0.009)\end{array}$ & $\begin{array}{l}-0.106^{* * * *} \\
(0.019)\end{array}$ & $\begin{array}{l}-0.089 * * * \\
(0.020)\end{array}$ & $\begin{array}{l}-0.105^{* * *} \\
(0.030)\end{array}$ \\
\hline Rural $\times$ migrants & & & & & $\begin{array}{l}0.286^{*} \\
(0.168)\end{array}$ & $\begin{array}{l}-0.011 \\
(0.204)\end{array}$ \\
\hline State FEs & Yes & Yes & Yes & Yes & Yes & Yes \\
\hline Year FEs & Yes & Yes & Yes & Yes & Yes & Yes \\
\hline State $\times$ year FEs & Yes & Yes & Yes & Yes & Yes & Yes \\
\hline No. observations & 36,413 & 3094 & 36,413 & 3094 & 36,413 & 3094 \\
\hline
\end{tabular}

Robust standard errors clustered at the state-by-survey year level in parentheses: * significant at $10 \%$, $* *$ significant at $5 \%, * * *$ significant at $1 \%$

${ }^{a}$ Columns 5 and 6 report estimates for specification (2). Both migrants and migrants $\times$ rural are instrumented. The instruments are potential migrants and potential migrants $\times$ rural

occurrence of pregnancy and the increased likelihood of the child to be delivered by a doctor among migrant households. Teenagers in migrant households have a higher knowledge of contraceptive methods and are more likely to practice active birth control. The impact of migration on the knowledge of at least one contraceptive method is very large, corresponding to a $37.4 \%$ increase. This result is in line with that found by De (2013): in Mexico, women from migrant families are $75 \%$ more likely to use birth control pills and $36 \%$ more likely to use condoms than their non-migrant counterparts. In the sample of all women, the statistically significant impacts are obtained among migrant households living in rural areas: women have a higher knowledge of 
contraceptive methods and their children are more likely delivered in safer conditions. Such an increased in the knowledge of birth control methods can be explained by better ability to process information due to higher access to education (wealth effect), transfer of behavioral norms through migrants' experience from the destination to the host country, and - especially for teenagers-decision to delay pregnancy in response of a decreased cost of migration.

Women's migration is expected to exert a stronger influence on the diffusion of contraceptive use and general health knowledge than men's migration (Lindstrom and Saucedo 2002). I investigate whether the gender of the migrant, precisely whether the existence of at least one sister who migrates to the United States, has an impact on the outcomes of interest. Nonetheless, households with female migrants comprise only $20 \%$ of my migrant sample and few observations can be considered in the analysis. The results are no longer statistically significant. ${ }^{33}$

\section{Conclusion}

Mexican migration to the United States is a long-standing phenomenon which has seen increasing flows of migrants over time and has strongly affected Mexican society. In this paper I investigated the impact of this migration on occurrence of pregnancy and child health care for those who remain in the country of origin. The main econometric challenge is the endogeneity of migrant status, which is solved by the use of an instrumental variable approach. Potential migration is used as instrument for current household migration to the United States. The principal channels through which migration affects fertility and child health care are wealth, transfer of behavioral norms from receiving to sending country communities and cost of migration. My data do not allow to provide a complete decomposition of these channels. However, I show some evidence of the increased health knowledge-measured as knowledge of contraceptive methods - among teenagers in households that experienced migration to U.S. and I argue that these girls may be better endowed to process information (wealth effect), decide to delay pregnancy (reduced cost of migration) and are more exposed to behavioral norms of the host country of their household members (knowledge transmission to the sending countries). Overall, the results show that having at least one household member who migrated to the United States decreases the occurrence of pregnancy among teenagers. Evidence of the increased knowledge of contraceptive methods which can partially drive this phenomenon is found. Being in migrant households increases the knowledge of contraceptive methods among teenagers: they likely practice active birth control behaviors. Less significant results are obtained for child care outcomes: being in a migrant household only raises the likelihood of the child to be delivered by a doctor in the sample of all women, especially in rural areas.

A part of the impact I find is undoubtedly related to the characteristics of the context I study. The wealth effect and the reduced cost of migration are widely documented in the literature as channels through which migration affects fertility and child health care. The transfer of behavioral norms from receiving to sending communities applies

33 The results are not reported but are available upon request. 
especially to those countries experiencing temporary and recurrent migration, as Mexico. More detailed data providing additional information on women' future migration and sources of knowledge of birth control methods would help to better understand the relative weight of these channels. Further investigation in this direction is encouraged and can integrate what I document in this paper.

Acknowledgments I would like to thank Eliana La Ferrara, Michele Pellizzari, Jean-Marie Baland, Andreas Madestam, Pedro Albarran, the AMID network, CRED-Centre de recherche en économie de développement (FUNDP) of Namur, and the participants of the 2010 CRED-LICOS workshops, Bocconi University Development Reading Group for their helpful comments and discussion. I thank the editor and anonymous referees for their comments and suggestions that helped to improve the paper. I am also grateful to officials at the Instituto Nacional de Estadística y Geografía (INEGI) for providing the data. Financial support from the Spanish MEC (Ref. ECO2014-58434-P) is gratefully acknowledged. I am responsible for any errors that may remain.

Open Access This article is distributed under the terms of the Creative Commons Attribution 4.0 International License (http://creativecommons.org/licenses/by/4.0/), which permits unrestricted use, distribution, and reproduction in any medium, provided you give appropriate credit to the original author(s) and the source, provide a link to the Creative Commons license, and indicate if changes were made.

\section{Appendix}

\section{A.1: Use of at least one contraceptive method}

Table 7 Use of at least one contraceptive method

\begin{tabular}{|c|c|c|c|c|c|c|}
\hline & $\begin{array}{l}(1) \\
\text { OLS } \\
\text { all }\end{array}$ & $\begin{array}{l}(2) \\
\text { OLS } \\
\text { teenagers }\end{array}$ & $\begin{array}{l}(3) \\
2 \text { SLS } \\
\text { all }\end{array}$ & $\begin{array}{l}(4) \\
\text { 2SLS } \\
\text { teenagers }\end{array}$ & $\begin{array}{l}(5) \\
2 S L S \\
\mathrm{all}^{\mathrm{a}}\end{array}$ & $\begin{array}{l}(6) \\
\text { 2SLS } \\
\text { teenagers }\end{array}$ \\
\hline Migrants & $\begin{array}{l}0.009 \\
(0.008)\end{array}$ & $\begin{array}{l}-0.002 \\
(0.041)\end{array}$ & $\begin{array}{l}-0.169 \\
(0.354)\end{array}$ & $\begin{array}{l}0.653 \\
(0.890)\end{array}$ & $\begin{array}{l}-0.603 \\
(0.632)\end{array}$ & $\begin{array}{l}0.898 \\
(2.502)\end{array}$ \\
\hline Rural & $\begin{array}{l}-0.081 * * * \\
(0.010)\end{array}$ & $\begin{array}{l}-0.120 * * * \\
(0.035)\end{array}$ & $\begin{array}{l}-0.074 * * * \\
(0.020)\end{array}$ & $\begin{array}{l}-0.159 \text { *** } \\
(0.058)\end{array}$ & $\begin{array}{l}-0.135^{\text {*** }} \\
(0.037)\end{array}$ & $\begin{array}{l}-0.132 \\
(0.108)\end{array}$ \\
\hline Rural $\times$ migrants & & & & & $\begin{array}{l}0.674 \\
(0.473)\end{array}$ & $\begin{array}{l}-0.308 \\
(1.718)\end{array}$ \\
\hline State FEs & Yes & Yes & Yes & Yes & Yes & Yes \\
\hline Year FEs & Yes & Yes & Yes & Yes & Yes & Yes \\
\hline State $\times$ year FEs & Yes & Yes & Yes & Yes & Yes & Yes \\
\hline No. observations & 26,406 & 1052 & 26,406 & 1052 & 26,406 & 1052 \\
\hline
\end{tabular}

Robust standard errors clustered at the state-by-survey year level in parentheses: * significant at $10 \%$, $* *$ significant at $5 \%, * * *$ significant at $1 \%$

The mean use of at least one contraceptive method among the full sample of sexually active women is 0.85 . It is 0.86 among non-migrant households and 0.85 among migrant households. Their difference is not statistically significant $[p$ value $=0.124$ ]. The mean use of at least one contraceptive method among the sample of sexually active teenagers is 0.69 . It is 0.70 among non-migrant households and 0.62 among migrant households. Their difference is statistically significant [ $p$ value $=0.002]$

${ }^{a}$ Columns 5 and 6 report estimates for specification (2). Both migrants and migrants $\times$ rural are instrumented. The instruments are potential migrants and potential migrants $\times$ rural 


\section{A.2: Further child-bearing for women with two or more children}

Table 8 Probability of further child-bearing for women with two or more children

\begin{tabular}{|c|c|c|c|c|c|c|}
\hline & (1) & (2) & (3) & (4) & (5) & (6) \\
\hline & All wom & & & Married & omen & \\
\hline Same sex & 0.006 & 0.021 & & 0.000 & 0.016 & \\
\hline & $(0.025)$ & $(0.029)$ & & $(0.027)$ & $(0.031)$ & \\
\hline Boy1st & & $-0.060 * * *$ & $-0.061 *$ & & $-0.065 * * *$ & $-0.059 *$ \\
\hline & & $(0.022)$ & $(0.034)$ & & $(0.024)$ & $(0.036)$ \\
\hline Age at first birth & & $-0.290 * * *$ & $-0.290 * * *$ & & $-0.302 * * *$ & $-0.302 * * *$ \\
\hline & & $(0.007)$ & $(0.007)$ & & $(0.008)$ & $(0.008)$ \\
\hline Age & & $0.251 * * *$ & $0.251 * * *$ & & $0.262 * * *$ & $0.262 * * *$ \\
\hline & & $(0.007)$ & $(0.007)$ & & $(0.007)$ & $(0.007)$ \\
\hline Two boys & & & 0.022 & & & 0.010 \\
\hline & & & $(0.040)$ & & & $(0.042)$ \\
\hline Two girls & & & 0.019 & & & 0.021 \\
\hline & & & $(0.037)$ & & & $(0.042)$ \\
\hline No. observations & 15,134 & 15,134 & 15,134 & 13,893 & 13,893 & 13,893 \\
\hline
\end{tabular}

Robust standard errors clustered at the state-by-survey year level in parentheses: * significant at $10 \%$, ** significant at $5 \%$, *** significant at $1 \%$

The mean number of children per woman is 3.25

\section{A.3: Wealth}

ENADID collects direct information on remittances and household income, but there are many missing values and inconsistent amounts. ${ }^{34}$ In order to measure the impact of migration on household income, I therefore create a wealth index: wealth is proxied by household durables and utilities and is defined through the first principal component analysis. ${ }^{35}$ I measure the impact of international migration on wealth index by using the same specification reported in the main analysis. Table 9 reports the estimates.

The results show that migration leads to a higher wealth index: on a scale between -8.3891 and 6.0967 , being in a migrant household increases wealth by 5.5 index points for all women and 2.66 index points for teenagers. Migrant households are richer and can plausibly spend more resources on human capital accumulation. Higher educated

\footnotetext{
34 Information on income-which also includes remittances-is not reliable: a high percentage of households report a monthly household income equal to zero Mexican pesos. If I exclude these observations, on average monthly household income ranges between 470 (in 1997) and 340 (in 2006) US dollars. In my sample, $12.4 \%$ of migrant households receive international (Mexico-U.S.) remittances and the monthly mean remittances are equal to 2,303 Mexican pesos, ranging from 292 to 212 US dollars depending on the year of the survey. 1 Mexican peso was equivalent to 0.12697 US dollars in 1997 and to 0.0919 in 2006.

35 Filmer and Pritchett (2001) showed that an index obtained through the first principal component can provide reasonable estimates of the wealth level effects in situations where wealth data are not directly available.
} 
Table 9 Wealth index

\begin{tabular}{|c|c|c|c|c|c|c|}
\hline & $\begin{array}{l}(1) \\
\text { OLS } \\
\text { all }\end{array}$ & $\begin{array}{l}(2) \\
\text { OLS } \\
\text { teenagers }\end{array}$ & $\begin{array}{l}(3) \\
2 \text { SLS } \\
\text { all }\end{array}$ & $\begin{array}{l}\text { (4) } \\
\text { 2SLS } \\
\text { teenagers }\end{array}$ & $\begin{array}{l}(5) \\
2 S L S \\
\text { all }^{a}\end{array}$ & $\begin{array}{l}(6) \\
2 \text { SLS } \\
\text { teenagers }^{a}\end{array}$ \\
\hline Migrants & $\begin{array}{l}0.086^{*} \\
(0.045)\end{array}$ & $\begin{array}{l}0.025 \\
(0.146)\end{array}$ & $\begin{array}{l}5.500 * * \\
(2.160)\end{array}$ & $\begin{array}{l}2.661 * * * \\
(0.841)\end{array}$ & $\begin{array}{l}7.522 * * * \\
(2.432)\end{array}$ & $\begin{array}{l}3.353^{* * *} \\
(0.943)\end{array}$ \\
\hline Rural & $\begin{array}{l}-1.075^{* * *} \\
(0.063)\end{array}$ & $\begin{array}{l}-1.065^{* * *} \\
(0.125)\end{array}$ & $\begin{array}{l}-1.322 * * * \\
(0.113)\end{array}$ & $\begin{array}{l}-1.227^{* * *} \\
(0.154)\end{array}$ & $\begin{array}{l}-0.882^{* * *} \\
(0.230)\end{array}$ & $\begin{array}{l}-1.077^{* * *} \\
(0.190)\end{array}$ \\
\hline Rural $\times$ migrants & & & & & $\begin{array}{l}-4.061 * \\
(2.445)\end{array}$ & $\begin{array}{l}-1.180 \\
(1.164)\end{array}$ \\
\hline State FEs & Yes & Yes & Yes & Yes & Yes & Yes \\
\hline Year FEs & Yes & Yes & Yes & Yes & Yes & Yes \\
\hline State $\times$ year FEs & Yes & Yes & Yes & Yes & Yes & Yes \\
\hline No. observations & 27,886 & 2411 & 27,886 & 2411 & 27,886 & 2411 \\
\hline
\end{tabular}

Robust standard errors clustered at the state-by-survey year level in parentheses: * significant at $10 \%$, $* *$ significant at $5 \%, * * *$ significant at $1 \%$

The mean wealth index is 0.00 for all women. It is -0.00 among non-migrant households and 0.02 among migrant households. Their difference is not statistically significant [ $p$ value $=0.580]$. The mean wealth index is -0.12 for the subsample of teenagers. It is -0.12 among non-migrant households and -0.17 among migrant households. Their difference is not statistically significant [ $p$ value $=0.517$ ]

${ }^{a}$ Columns 5 and 6 report estimates for specification (2). Both migrants and migrants $\times$ rural are instrumented. The instruments are potential migrants and potential migrants $\times$ rural

women can thus better process information and acquire more health knowledge with consequences on fertility and child health care. There is a differential impact due to the location of the household: both all women and teenagers in urban migrant households have a higher wealth index than their peers in non-migrant households.

\section{References}

Angrist J (1991) Instrumental variables estimation of average treatment effects in econometrics and epidemiology. NBER Technical working papers 0115, National Bureau of Economic Research Inc

Angrist JD, Evans WN (1998) Children and their parents' labor supply: evidence from exogenous variation in family size. Am Econ Rev 88(3):450-477

Becker GS (1960) An economic analysis of fertility. In: Demographic and economic change in developed countries, NBER Chapters, Universities-National Bureau. Columbia University Press, pp 209-240

Becker S, Costenbader E (2001) Husband and wives' reports of contraceptive use. Stud Family Plann 32(2):111-129

Beine M, Docquier F, Schiff M (2013) International migration, transfers of norms and home country fertility. Can J Econ 45(4):1406-1430

Bertrand M, Luttmer E, Mullainathan S (2000) Network effects and welfare cultures. Quart J Econ 115(3):1019-1055

Bicego G, Ahmad OB (1996) Infant and child mortality. In: Demographic and health surveys, comparative studies., vol 20. Macro International Inc, Calverton, Maryland

Borjas GJ, Katz LF (2007) The evolution of the Mexican-Born workforce in the United States. In: Mexican immigration to the United States, NBER Chapters, National Bureau of Economic Research Inc., pp 13-56 
Breierova L, Duflo E (2004) The impact of education on fertility and child mortality: do fathers really matter less than mothers? NBER working papers 10513, National Bureau of Economic Research Inc

Buvinic M (1998) The costs of adolescent childbearing: evidence from Chile, Barbados, Guatemala, and Mexico. Stud Family Plann 29(2):201-209

Chou T (2011) Is fertility decline contagious? Trans-Atlantic norm shifts and fertility in the post-vatican II period. Essays in labor economics. UC San Diego: b7075218

CONAPO (1998) Boletín de Información Estadística, Recursos y Servicios (1997) Technical report, Dirección General de Estadística e Informática

CONAPO (2002) Proyecciones de la Población de Mexico, 2000-2005. Technical report, Dirección General de Información en Salud. Sistema Nacional de Información en Salud. Secretaria de Salud, CONAPO, Mexico

CONAPO (2007) Programa Nacional de Salud 2007-2012. Technical report, Dirección General de Información en Salud. Sistema Nacional de Información en Salud. Secretaria de Salud, CONAPO, Mexico

Cox D, Hansen BE, Jimenez E (2004) How responsive are private transfers to income? Evidence from a Laissez-Faire economy. J Public Econ 88(9-10):2193-2219

De PK (2013) Cultural transmission and contraceptive use-evidence from USA-Mexico migration. Migrat Dev 2(2):286-311

Deri C (2005) Social networks and health service utilization. J Health Econ 24(6):1076-1107

Devillanova C (2008) Social networks, information and health care utilization: evidence from undocumented immigrants in Milan. J Health Econ 27(2):265-286

Duncan T, Strauss J, Henriques M (1991) How does mother's education affect child height? J Human Resour 26(2):183-211

Durand J, Massey D, Zenteno R (2001) Mexican immigration to the United States: continuities and changes. Lat Am Res Rev 36(1):107-127

Fargues P (2006) The demographic benefit of international migration: Hypothesis and application to middle Eastern and North African contexts. In: International Migration, economic development and policy. The World Bank and Palgrave Macmillan, pp 161-182

Filmer D, Pritchett L (2001) Estimating wealth effects without expenditure data or tears: an application to educational enrollments in States of India. Demography 38(1):115-132

Foerster R (1925) The racial problems involved in immigration from Latin America and the West Indies to the United States. The United States Department of Labor, Washington, DC

Frank R, Hummer RA (2002) The other side of the paradox: the risk of low birth weight among infants of migrant and non-migrant households within Mexico. Int Migrat Rev 36(3):746-765

Hildebrandt N, McKenzie DJ (2005) The effects of migration on child health in Mexico. Economia 6(1):257289

INEGI (2000) Mexican Census. Instituto Nacional de Estadística y Geografía

INEGI (2005) Conteo de Población y Vivienda. Instituto Nacional de Estadística y Geografía

IPUMS (2010) Tables SDA 3.3.- Number of own children in the household by origin. CSM, UC Berkeley

Kanaiaupuni SM, Donato K (1999) Migradollars and mortality: the effect of U.S. migration on infant survival in Mexico. Demography 36(3):339-353

Kovsted J, Portner CC, Trap F (2002) Child health and mortality: does health knowledge matter? J Afr Econ 11(4):542-560

Lindstrom DP, Munoz-Franco E (2005) Migration and Diffusion of modern contraceptive knowledge and use in rural Guatemala. Stud Family Plan 36(4):277-288

Lindstrom DP, Saucedo SG (2002) The short- and long-term effects of U.S. Migration experience on Mexican women's fertility. Soc Forces 80(4):1341-1368

Mansuri G (2006) Migration, sex bias, and child growth in rural Pakistan. Policy Research working paper series 3946, The World Bank

Massey D, Durand J, Malone NJ (2002) Beyond smoke and mirrors: Mexican immigration in an era of economic integration. Russell Sage Foundation, New York

Massey D, Goldring L, Durand J (1994) Continuities in transnational migration: an analysis of nineteen Mexican communities. Am J Sociol 99(6):1492-1533

Menjivar C (2002) The ties that heal: Guatemalan immigrant women's networks and medical treatment. Int Migrat Rev 36(2):437-466

Munshi K (2003) Networks in the modern economy: Mexican migrants in the U.S. labor market. Quart J Econ 118(2):549-599 
Newey W (1987) Efficient Estimation of limited dependent variable models with endogenous explanatory variables. J Econ 36(3):231-250

Reynolds HW, Wong EL, Tucker H (2006) Adolescents' Use of maternal and child health services in developing countries. Int Family Plan Perspect 32(1):6-16

Rosenzweig MR, Schultz TP (1987) Fertility and investments in human capital: estimates of the consequence of imperfect fertility control in Malaysia. J Econ 36(1-2):163-184

Save the Children (2004) Annual report. Save the Children

Stock J, Yogo M (2005) Testing for weak instruments in linear IV regression. In: Andrews DWK (ed) Identification and inference for econometric models. Cambridge University Press, New York, pp 80108

UNDP (2007) Annual report. UNDP

United Nations (2002) Annual report. The population policy data bank

U.S. Census Bureau (2006) U.S. Census. U.S. Census Bureau

U.S. Hhs (2007) Child Health USA 2007 Health Resources and Services Administration, Maternal and Child Health Bureau. U.S. Department of Health and Human Services, Rockville, Maryland, p 2008

Weil DN (2005) Economic growth (ch.4). Pearson/Addison-Wesley, Boston

Winters P, de Janvry A, Sadoulet E (2001) Family and community networks in Mexico-U.S. migration. J Human Resour 36(1):159-184

Woodruff C (2007) How does migration affect local develoment? What Mexico's experience tells us. In: Pozo S (ed) Immigrants and their international money flows. Western Michigan University, Kalamazoo 